\title{
Implementation of Index for Inclusions as Development of Inclusive Education
}

\author{
Triworo Parnoningrum \\ Doctoral Education of Management Program \\ Universitas Negeri Surabaya \\ Surabaya, Indonesia \\ triworoparnoningrum@mhs.unesa.ac.id
}

\begin{abstract}
Surabaya currently has 20 secondary schools as the organizers inclusive education. Junior high school 28 Surabaya is one of the organizers of inclusive education schools in Surabaya. This year serving eight disability students with a variety of special characters including autism, disabled and slow learners. It requires friendly school management for students of character diversity.

The objective was to develop inclusive education at disability children at Junior High School 28 Surabaya as an effort to: 1) improve the index for inclusion to develop inclusive education, 2) improve the culture, policy and practise teacher in school 3) Enhancement of teacher skills and knowledge to better address the learning needs of all students. This paper used discriptif qualitative method.

The recently developed Index for Inclusion is one resource that can facilitate the process of professional and facilitate change in school culture, policy and teaching practice at Junior high school 28 Surabaya. The Index process described in this paper incorporates the use of a critical friends and peers mentoring within an action research model to provide benefits for all involved in the professional development process. This paper reports on the initial stages of a collaborative partnership for all school stakeholders in a disadvantaged socio-economic area of Junior high school 28 Surabaya. The stages of the journey of learning incorporating the Index for Inclusion are reported.
\end{abstract}

Keywords - inclusive education, disability children, index for inclusions.

\section{INTRODUCTION}

Education in Indonesia lately shocked by a discourse that had great influence on the lives of future generations of the nation is about inclusive education. The right to an adequate education services are also protected by the government as stipulated in the Constitution RI Chapter XIII Article 31, which contains: (1) Every citizen is entitled to education.
Inclusive education is an education that provides opportunity and equal service to all students, particularly students with special needs to receive the same learning experiences with their peers in regular classes. It aims to make education as a place of socialization for students who have special needs to be able to live naturally and getting the same treatment with the other students. But in reality, many schools still do not dare to provide inclusive education services. It is caused by several factors, including:

1. Lack of understanding of the nature of inclusive education.

2. Lack of human resources who have the knowledge and insight about inclusive education services.

3. Lack of infrastructure for air services to special needs students.

The last 10 years, inclusive education began to be implemented at all levels in junior high school in the city of Surabaya, to accommodate elementary school graduates from the Inclusive education providers who have difficulties to direct graduates to proceed to a higher level. Education office in Surabaya since 2008 gradually appoint 20 junior high schools as an organizer of inclusive education, including Junior High School Surabaya which started organizing Inclusive Education since 2014 to accommodate students with special needs who reside in the area districts Mulyorejo Surabaya. JHS 28 Surabaya in developing inclusive education using the index guide inclusive in the process of development.

Through this paper, the author wishes to share experience on " How Implementation of Index for Inclusions as Development of Inclusive Education at Junior High School 28 Surabaya, Indonesia?" This paper aims to explore the motivation of the various implementing inclusive education from state schools in particular and other public schools to implement inclusive education in various forms and methods. 


\section{A. The legal basis for Inclusive Schools}

\section{Philosophical Basis}

Inclusive education is based on the spirit of education that is open to embrace all people in education. Inclusive Education is the implementation of the five pillars at the same ideals of Pancasila, namely BHINNEKA TUNGGAL IKA (Mulyono Abdurrahman, 2003), an educationminded multicultural that can help learners understand, accept and respect other people of different tribes, cultures, values, personality, and physical and psychological functioning.

\section{Formal Juridical Basis}

- The UN Convention year 1989 on The Rights of The Child

- Declaration of Education for All year 1990 in Thailand

- Salamanca declaration year 1994 on The Inclusive Education

- Act of RI No. 4 year 1997 on The Persons with Disabilities

- Act of RI No. 23 year 2003 on The Protection of Rights of the Child.

- Government Regulation No.19 year 2004 on The National Education Standards.

- Bandung Declaration year 2004 on Towards Inclusive Education.

- Ministerial Regulation No. 70 year 2009 on The Implementation of Inclusive Education

- The East Java Governur Regulation No.11 year 2011 on on The Implementation of Inclusive Education in The province of East Java.

\section{Pedagogical Basis}

In Article 3 of Act of RI No. 20 year 2003, stated that the purpose of national education is the development of students' potentials to become a man of faith and fear of God Almighty, noble. healthy, knowledgeable, capable, creative, independent, and become citizens democratic and accountable. So, through education, learners with disabilities formed into citizens of a democratic and responsible, i.e. individuals who are able to appreciate the differences and participate in the community. This goal is impossible to achieve if from the beginning they were isolated from their peers in special schools. However small, they should be given the opportunity together with peers.

\section{B. Classification of Child with Special Needs}

In accordance with the Program Directorate of Special Schools year 2006 and Guidance of Directorate General Primary and Secondary Education of National Education Department are as follows:

1. Blind

2. Deaf

3. Mental Retardation: (a.1. Down Syndrome)

4. Mental Retardation Lightweight (IQ = 50-70)

5. Mental Retardation Medium (IQ $=25-50)$

6. Mental Retardation Weight (IQ 125)

7. Talented: Potential special talent (Multiple Intelligences: Language, Logico mathematic, Visuo-spatial, Bodily-kinesthetic, Musical, Interpersonal, Intrapersonal, Natural, Spiritual).

8. Learning Disabilities (i.e. Hyperactive, ADD / ADHD, Dyslexia / Read, Dysgraphia / Write, Dyscalculia / Compute, dysphasia / Talk, Dyspraxia / Motor)

9. Slow Learning (IQ $=70-90)$

10. Autism

11. Drug Abusers

12. Indigo

\section{DESIGN/PROCEDURE}

Project implementation of Index for Inclusion in Junior High School 28 (JHS) Surabaya through 5 phases:

a. Phase I: Establishing the foundation. Can be done by creating a special committee for the project for inclusion index which consists of teachers, special education teachers, parents and students

b. Phase II: Review and collate setting. Schools can review dimension to be taken then choose the most appropriate setting and develop.

c. Phase III: Plan, implement and transfer of knowledge/understanding. All elements of the school sought must work together to support the setting that has been compiled. Plan, can be started with planning a survey in schools for all school members either online or through a wall magazine

d. Phase IV: Reviewing and build capacity. After the team do the third step, the review should be done to see the extent to which the capacity of project implementation in schools.

e. Phase V: Ensuring the sustainability of the program and look at the implications of the program

Stages of Development of Inclusive Education based on Dimensions Inclusive Index of JHS 28 Surabaya: 
1) Dimensions A : Creating a Culture of Inclusion are Building a community consist of everyone feels welcome, students help each other, the teachers cooperate with one another, teachers and students treat each other with respect, there is a partnership between teachers and parents / guardians, teachers and government work together well, all local communities are involved in school. Creating value inclusive consist of the presence of high expectations for all pupils, master, governments, students and parents / carers share a philosophy of inclusion, students have the same values, teachers and students treat one another as human beings as well as their role holder, the teacher tried to eliminate barriers to learning and participation in all aspects of school, schools strive to minimize all forms of discrimination

2) Dimensions B : Produces inclusion policies are Developing schools for all consist of designation and the increase of children by teachers is fair, all new teachers feel comfortable, air B.1.3 School seeks to admit all students from their territory, schools make the building accessible to everyone, all new students can feel comfortable in school, school designed a teaching group appreciated that all students in school. Supports the values of difference consist of all forms of coordinated assistance, development activities of teachers helping teachers to respond to student differences, special education policy is a policy of inclusion, regulation / law enforcement special education to reduce barriers to learning and participation of all students, give English as an additional language learning support co-ordinated with, religious activities and behaviour helps policy to link curriculum develop ment and learning support policies, emphasis regarding exclusion reduced, factors leading to reduced absenteeism, minimized Violence

3) Dimension $\mathbf{C}$ : Preparation of Inclusive Implementation are Implementation of a comprehensive learning consist of teaching is planned based mindset of students, lessons encourage the participation of all pupils / instruction encourages all students to participate, lessons develop an understanding of the differences, students are actively involved in their learning process, students learn in groups, evaluation contributes to the attainment / achievement of all students, class Discipline is based on mutual respect, teachers design, teaching, reviewing teamwork, learning help support the learning process and the involvement of all students, contributes to all parties for parents, all students take part in outside of the classroom. Deploy Resources consist of differences pupils used as a source for learning and teaching Expertise, teachers fully utilized, teachers develop resources to support learning and participation 3, community resources are known and described, school resources are distributed fairly so that they support inclusion

\section{FINDING/ANALYSIS}

\section{A. The SWOT Analysis}

SWOT Analysis is a strategic planning instrument classic. By using the framework's strengths and weaknesses and external opportunities and threats, This instrument provide a simple way to estimate the best way:

\section{Strength:}

- The spirit and motivation of many teachers who are enthusiastic about caring for inclusive education program in schools.

- Most of the students have a high awareness to the students with the special needs.

- A large number of Inclusive of State Elementary School

- The issuance of Decree Head of Education Office on JHS 28 Surabaya as the organizer of inclusive schools.

- Publication of Education Ministerial Regulation No. 70 year 2009 on the implementation of Inclusive Education

- Publication of East Java Governor Regulation No. 06 year 2011 on the implementation of Inclusive Education

- The support of principals that apply the paradigm that the educator is a learner and the learner as well as agents of renewal throughout life.

- Support from the school committee in developing an inclusive education program in schools

- Support of Inclusive PLB Team of Surabaya State University as an assistant in implementing inclusive education program in schools

- Support from local and central government assistance in the form of an increase in Human Resources, Finance and Infrastructure.

\section{Weaknesses}

- Lack of concern for some teachers, school employees and the surrounding community about the existence of the students with special needs.

- Lack of understanding most of stakeholder about the nature of inclusive education. 
- Lack of teachers who have the knowledge and insight about inclusive education services.

- Lack of infrastructure facilities to support services for students with special needs

- The absence of a model school for the holding of an inclusive schools

\section{Opportunities}

- Attention central and local governments become larger.

- Increase the value of humanity and equality for every student and citizens of school in general.

- Improve school achievements in the field of character education.

- Teachers and employees have a great opportunity to get an education training on inclusive education services.

- Increase the value of prestige schools secure equal human rights and the rights of children in education

\section{Threat}

- The parents generally assume that they are afraid of achievement and behavior of their children will be affected by students with special needs.

- The presumption several teachers who felt his teaching duties in regular classes disrupted because of the behavior and attitudes of students with special needs.

\section{B. Implementation Process}

\section{Identification of student}

The identification is done with the following steps:

a. Children collect data

At this stage officers (teachers) collect data on the condition of all students in the class (based on symptoms which appear on the student) using the Identification Tool of Children with Special Needs (CSN)

b. Analyzing Data and Classifying Children

At this stage the aim is to find the children categorized in Children with Special Needs (CSN) (which require special education services). Make a list of names of children who indicated a disability in accordance with the characteristics. If there are children who are eligible to be called or indications of abnormality in accordance with these provisions, then put in the list of names of children who indicated abnormalities. As for children who do not show symptoms or signs of disability, do not need to put in the special list.

c. Inform Analysis and Classification

At this stage, the analysis and classification have been made implementing teacher identification, be reported to the principal, parents, homeroom to get suggestions for solving or follow-up.

d. Organizing Discussion Case (case conference)

At this stage, activities are coordinated by the Principal after the Children with Special Needs (CSN) data collected of the entire class. Principal may involve: (1) Principal itself; (2) Council of Teachers; (3) the parents/guardians of students; (4) professional personnel related, if available and feasible; (5) Advisors/Special Education Teachers (Teacher of CSN) if available and enabled.

Meeting materials case was to discuss the teacher findings about the results of identification to get a response and how to prevent and mitigate them.

e. Develop Individual learning program

At this stage, the team is preparing an agreement document preparation, process and outcomes of learning achievement achieved by students during the school year

\section{Type Program services}

Based on identification and the assessment on the Children with Special Needs (CSN), the teacher can determine the type of services program for the students. The type of service programs in teaching and learning were applied in JHS 28 Surabaya is as follows:

\section{a. Special Class}

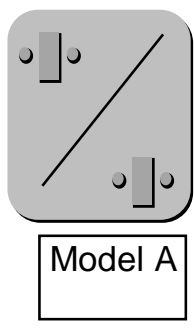

Model A
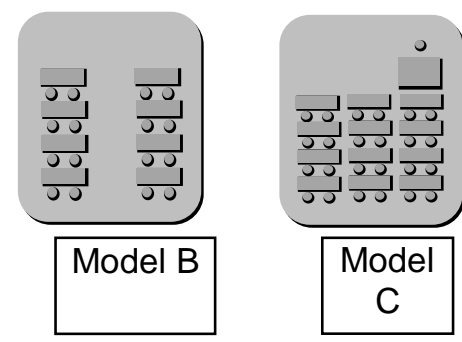

Intended for CSN still require maximum intervention, especially for students who have behavioral disorders. In this model the students guided by a teacher in a special room.

\section{Model B}

In this model CSN learning in special classes along with other crew members still get the full guidance (one teacher-one student).

\section{Model C}

An advanced service model for students who are able to learn the patterns of semi-classical guided by the main Special Advisors teachers (SAT), but still 
accompanied by a tutor who serves as shadow (companion)

\section{b. Pre- classical Class}

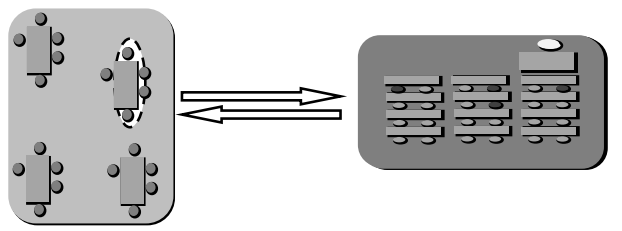

Some crew with capabilities similar study in a study group led by the Special Advisors teachers (SAT) in the source chamber along with the other study groups, but in specific subject areas (e.g. Sports, Arts, Skills, English, and Religion ) and the same class (level) can learn together regular students in the class classical.

\section{c. Remedial Class}

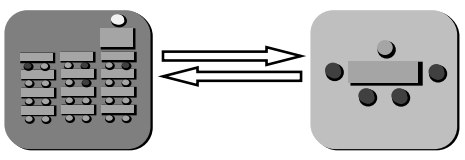

Remedial classes is the Children with Special Needs (CSN) mild, in regular classes who have problems / obstacles (concentration) in almost all fields of study then drag it to the class resources (resources room), performed throughout the day, with a load of the same curriculum with classical children with the guidance of Special Advisors teachers (SAT).

\section{d. Companion Class}

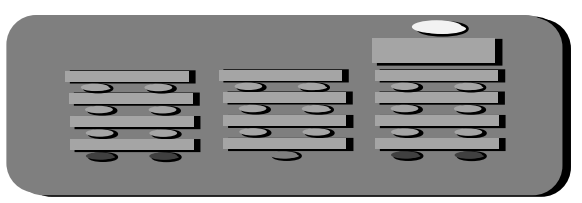

The companion class is the Children with Special Needs (CSN) study with other children (normal) in regular classes throughout the day. They are guided by the main teacher as presenter of material, but in the group CSN by AST as a shadow.

\section{e. Full Inclusion Classes}

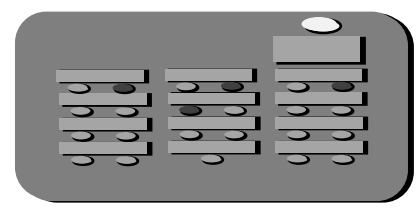

Full inclusion class is the Children with Special Needs (CSN) to learn throughout the day in regular classes by using the same curriculum loads without assistance.

\section{Curriculum and Lesson Methods}

JHS 28 Surabaya apply 3 curriculum model, namely:

a. The Duplication curriculum model

The students with special needs:

- follow a general curriculum

- In the regular classroom

- It is expected that the crew can follow the general classroom learning in the classical with the children of other general.

b. The modification curriculum model

The students with special needs:

- follow a modification curriculum

- Implement substitution or omission of the method, manner and subject matter .

- In the regular classroom or in special classes

- Special service program is more geared to the guardianship of learning, learning motivation and perseverance.

- Formulated based on the result of the assessment conducted by special education teachers with the team of experts concerned.

Determination of the model curriculum and teaching methods carried out by the regular teacher educators, teachers escort students' inclusion in the school teacher's forum activities every field of study.

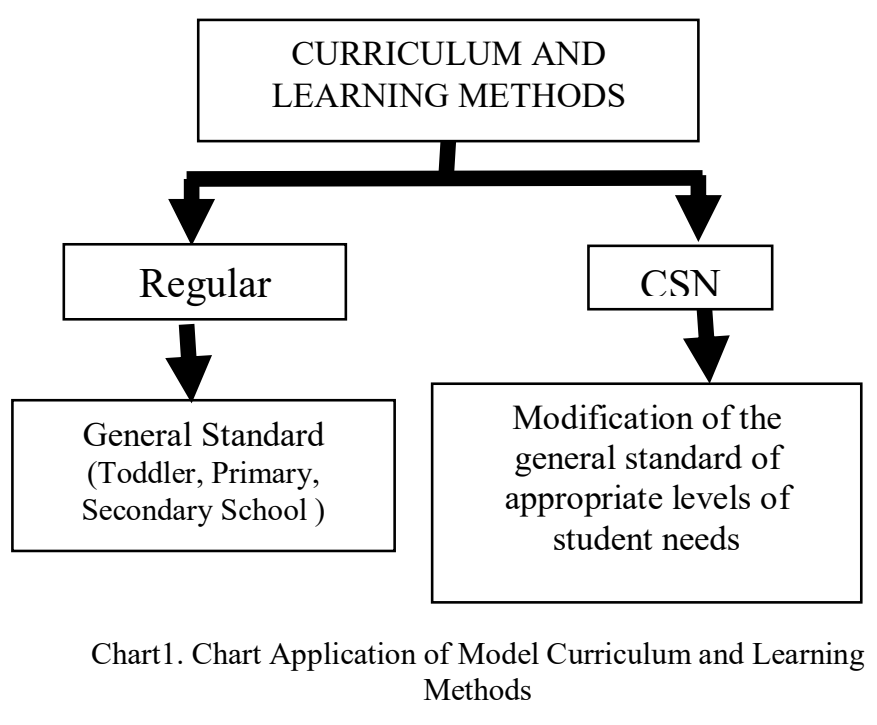

\section{Assessment or evaluation}

Evaluation of the students who have special needs in the JHS 28 Surabaya carried out in accordance with the curriculum of different programs on each type of student services. Results of the 
evaluation on the students with special needs are shown in the form of value achievement value is achieved in the process of academic and motivational value is numeric value is displayed in the form of sentences motor development during the learning process.

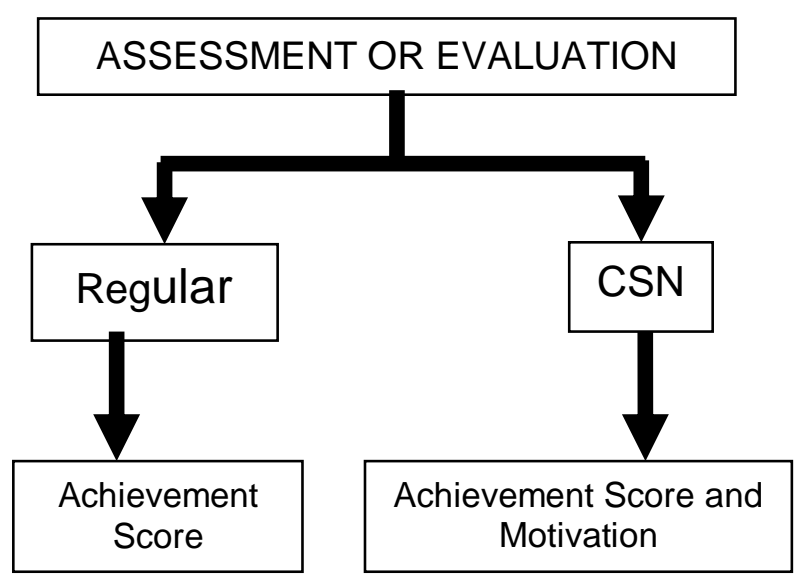

Chart 2. Chart Assessment or Evaluation

\section{Progress Report Student Results}

Progress reports for students learning achievement air special needs in JHS 28 Surabaya has three book reports, namely:

a. Liaison Book

A book that connects parents and teachers about student activities at school and at home

b. Quarterly Progress Report Book

The Books about motor development of students report given to parents every three months of school.

c. Reports Books Per-semester (report cards): Numeric, Description / Narrative and Competence.

Books about the results of student achievement in the form of numeric values and are described in narrative form.

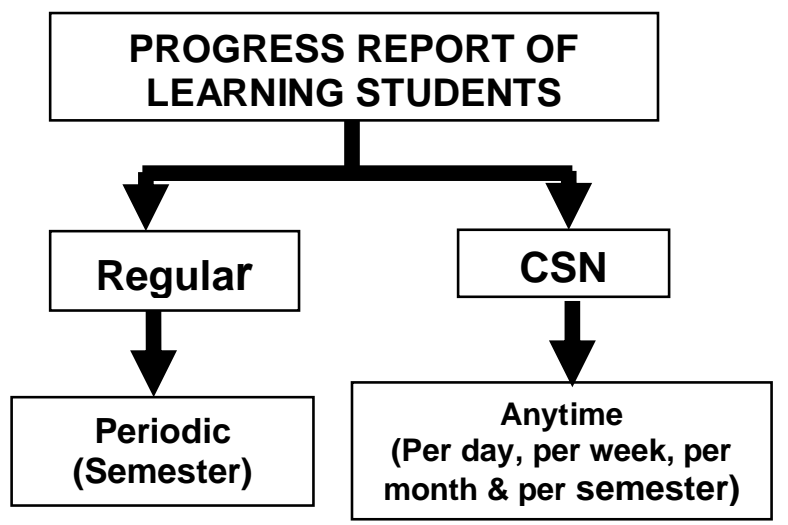

Chart 3. Chart Progress Report Student Results

\section{CONCLUSION AND RECOMENDATIONS}

\section{Conclusion}

Stages of implementation of inclusive education in accordance inclusive index: Build an inclusive culture in all school stakeholders, creating inclusive policies that favor the formation of the Inclusive Culture and learning process with inclusive services, perform analysis of the identification and the assessment of students ber special needs, determine the appropriate character of individual learning program services students with special needs, implement the Learning Process according to type of program services students, conduct an evaluation according to the type of service program students, determine the type of advanced service program. Constraints faced by school are lack of awareness and quality of human resources to serve students in inclusive, limitations of accessibility in schools, limitations of operational funds, limitations of the supporting props, study room / source is not maximized. The solution to solve the problem are cooperating with the various agencies concerned to inclusive education, provide education and training for teachers of the advisory team of experts from universities related to inclusive education, creating mini space but optimal learning resources to support inclusive student learning process

\section{Recommendations}

Lack of skilled human resources in the teachers serving students ber special needs and the limited facilities and infrastructure in a school institution, it is necessary: Perform active communication (instructions) of the Department of Education, provincial and central levels. Open network with inclusive schools and other special schools. Organizing cooperation with local LPTK as a companion inclusive school. Open the spillover schools, Improve collaboration with education observers and Parent of special needs students

\section{References}

[1] Act of Republic Indonesia No. 20 Year 2003 on National Education System. Jakarta

[2] Depdiknas (2009) TOT modules for the implementation of Inclusive Education, Jakarta Depdiknas

[3] Hildegum Olsen, (2003) Inclusive Education: a strategy towards Education for All (Material Workshop) Mataram : Direktorat PSLB

[4] Gillies, Robyn M. and Carrington, Suzanne (2004) Inclusion: Culture, Policy and Practice: A Queensland Perspective.Asia Pacific Journal of Education24(2):117-128. 
[5] Triworo P (2009), Inclusive education curriculum development, Surabaya: Hand out the workshop on inclusive education in SMPN 4 Gresik

[6] Ainscow, M. (2008). Teaching for diversity: the next big challenge: The Sage handbook of curriculum and instruction. USA: Sage Publications, Inc.

[7] Carrington, S. \& Macartur, J. (eds.). (2012). Teaching in inclusive school communities. Milton Qld, Australia: John Wiley \& Sons Australia, Ltd.
[8] Departemen Pendidikan Nasional. (2003). Undang-Undang Republik Indonesia Nomor 20 Tahun 2003 tentang Sistem Pendidikan Nasional. Jakarta: Depdiknas.

[9] Direktorat PPK-LK. (2011). Pedoman umum penyelenggaraan pendidikan inklusif. Jakarta: Kementerian Pendidikan dan Kebudayaan.

[10] Smith, D.J. (2012). Inclusion, school for all student. Penerjemah: Denis E. Bandung: Penerbit Nuansa. 